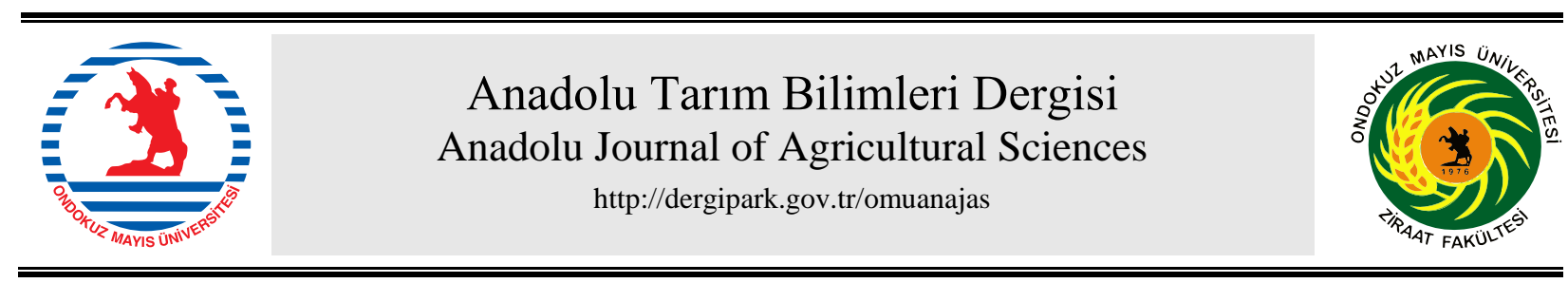

Araştırma/Research

Anadolu Tarım Bilim. Derg./Anadolu J Agr Sci, 36 (2021)

ISSN: 1308-8750 (Print) 1308-8769 (Online)

doi: 10.7161/omuanajas.931793

\title{
Çanakkale ilinde Rose yellow vein virus etmeninin tespiti ve genetik çeşitliliği
}

\author{
๑Nazlı Kısa, @Savaş Korkmaz \\ Çanakkale Onsekiz Mart Üniversitesi, Ziraat Fakültesi, Bitki Koruma Bölümü, Çanakkale, Türkiye
}

*Sorumlu yazar/corresponding author: skorkmaz@ comu.edu.trr

Geliş/Received 03/05/2021 Kabul/Accepted 31/08/2021

\begin{abstract}
ÖZET
Ülkemizin hemen hemen her bölgesinde güller (Rosa spp.) doğal olarak yetişmekte veya üretimi yapılmaktadır. Güllerde enfeksiyon oluşturan çok sayıda virüs hastalığı vardır ve bunlardan bir tanesi de Rose yellow vein virus (RYVV)'dür. RYVV Caulimoviridae familyası içinde Rosadnavirus cinsine ait bir virüstür. Virüs, 9.314 nükleotitten oluşan ssDNA $(+)$ genomuna sahiptir. Etmen ülkemiz için yeni bir virüs olup karakterizasyonu tam olarak yapılmamıştır. Çalışma kapsamında 2018-2019 yıllarında Çanakkale ilinde virüs ve virüs benzeri simptom gösteren 71 gül örneği toplanmıştır. Toplanan örnekler PCR ile k1lıf protein genine spesifik primer çifti ile test edilmiştir. Testlemeler sonucunda 71 örneğin 19'u enfekteli olarak bulunmuştur. Enfekteli izolatlardan biri seçilerek ilgilenilen hareket proteini (movement protein; $M P$ ) ve kıllf proteini (coat protein; $C P$ ) gen bölgelerinin tamamı PCR ile amplifiye edilmiştir. Elde edilen PCR ürünleri kullanılarak seçilen izolata ait amplifiye edilmiş olan $M P$ ve $C P$ genlerinin nükleotid dizileri belirlenmiştir. Elde edilen RYVV $M P$ ve $C P$ genlerine ait nükleotit dizilimleri kullanılarak, amino asit dizilimleri çıkarılmıştır. Yapılan nükleotid ve amino asit temelli çoklu dizi karşılaştırmaları sonucunda Çanakkale RYVV izolatı ile dünya izolatları arasında nükleotid düzeyinde \%96-98, amino asit düzeyinde \%98-99 oranlarında benzerlik olduğu tespit edilmiştir. Ayrıca filogenetik analizler sonucunda Çanakkale RYVV izolatı ile dünya izolatlarının ilişkileri ortaya koyulmuştur. Bu çalışma ile ülkemizde ilk defa RYVV Çanakkale izolatııın iki gen bölgesine göre moleküler karakterizasyonu gerçekleştirilmiştir.
\end{abstract}

Detection and genetic diversity of Rose yellow vein virus in Çanakkale province, Turkey

\section{ABSTRACT}

Roses (Rosa spp.) are naturally grown or produced in almost every region of Turkey. There are numerous viruses that infect roses, including the Rose yellow vein virus (RYVV). RYVV belongs in the genus Rosadnavirus and the family Caulimoviridae. The virus has a ssDNA (+) genome that consists of 9.314 nucleotides. RYVV is a new virus to Turkey and it hasn't yet been characterized. For this reason, 71 roses showing virus and virus-like disease symptoms were collected from Çanakkale province in 2018-2019. The collected samples were tested by PCR with the coat protein gene-specific primer pair. As a result of the tests, 19 out of 71 samples were found to be infected with RYVV. One isolate was randomly selected and the gene regions, movement protein $(M P)$, and coat protein $(C P)$ were amplified by PCR and the PCR products were sequenced. The amino acid sequences of the RYVV MP and $C P$ genes were deduced by nucleotide sequence analysis. As a result of multiple sequence comparisons based on two gene regions of the nucleotide and deduced amino acid, the Çanakkale RYVV isolate showed $96-98 \%$ nucleotide and $98-99 \%$ amino acid similarities with known isolates, respectively. Moreover, as a result of phylogenetic analysis, relationships between the Çanakkale RYVV isolate and the known isolates were revealed. This study was the first to perform molecular characterization of the RYVV Canakkale isolates, based on two gene regions, in Turkey.

Anahtar Sözcükler:

Gül

PCR

Virüs

RYVV
Keywords:

Rose

PCR

Virus

RYVV

(C) OMU ANAJAS 2021 


\section{Giriş}

Süs bitkileri, genellikle ürünlerinden çok estetik güzellikleri sebebiyle üretimi yapılan bitkilerdir. Bugün ticari amaçla sürdürülen süs bitkileri ve çiçek üretimi gün geçtikçe büyüyen bir sektör halini almıştır. Bu konuda çoğu ülkede büyük yatırımlar yapılmakta olup bu ülkeler arasında bir rekabet bulunmaktadır (Korkut, 1998).

Süs bitkileri 4 temel grup içinde değerlendirilmektedir. Bunlar; dış mekan süs bitkileri, saksılı salon bitkileri, doğal çiçek soğanları ve kesme çiçeklerdir (Titiz ve ark., 2000; Yazgan ve ark., 2005; Yılmaz, 2009). Üretim bakımından bu gruplar incelendiğinde ilk sırada \%68,6 ile kesme çiçek yer alırken bunu \%27,2 oranla dış mekan süs bitkileri takip etmektedir (Anonim, 2016). Ülkemiz için en önemli süs bitkilerinden bir tanesi ise güldür (Rosa spp.). Her bitki türünde olduğu gibi güllerin de hastalık ve zararlıları bulunmakta olup çeşitli enfeksiyonlar sonucu çiçek veriminde ve kalitede kayıplar meydana gelmektedir. Horst ve Clody (2007), güllerde zararlar meydana getirerek çiçek kalitesini ve verimini düşüren 26 farklı biyotik hastalık etmeninin olduğunu bildirmiştir. Ayrıca bu biyotik hastalık etmenlerine ek olarak abiyotik etmenlerinde fizyolojik bozukluklara neden olduğunu belirtmiştir. Oluşan bu kayıpların verim ve kalite üzerinde olumsuz şekilde etki ettikleri de bilinmektedir.

Dünyada gerçekleştirilen çalışmalar sonucunda gülleri enfekte eden 11 farklı virüs hastalığı tanımlanmıştır (Horst ve Cloyt, 2007; Karanfil, 2021). Bu etmenlerden en yaygin olanlar ise Prunus necrotic ringspot virus (PNRSV), Arabis mosaic virus (ArMV), Apple mosaic virus (ApMV) olarak bildirilmiştir. Gül yapraklarında çizgili lekeler, rozetleşme, yaprak kıvırcıklığı, halkalı leke, cücelik, solgunluk, çiçeklerde renk açılması ve şekil bozukluklarına sebep olan virüsler saptanmasına rağmen bazıları çok özel koşullarda lokal olarak ve nadiren karşımıza çıkan virüs hastalıklarıdır. Güllerde çiçek kalitesi ile verimini düşüren virüs kaynaklı hastalıkların, dünyanın birçok yerinde görüldüğü ve bu hastalıklar üzerine araştırmaların devam ettiği bilinmektedir.

Son y1llarda ABD'de güllerde damar sararma hastalığının etmeni olarak caulimovirus benzeri olarak sinıflandırılan Rose yellow vein virus (RYVV) etmeni tanımlanmıştır (Lockhart ve ark., 2011). Virüs, daha sonra yapılan çalışmalarda Caulimoviridae familyasında Rosadnavirus cinsi içinde sınıflandırılmıştır. RYVV 9314 nükleotidden oluşan, toplam 8 açık okuma bölgesi içeren, sirkülatif tek parçalı dsDNA genomuna sahiptir (Milleza ve ark., 2013). RYVV, ABD dişında ilk olarak Yeni Zelanda'da tek bir gül örneğinden tespit edilmiş (PerezEgusquiza ve ark., 2012), ancak mevcut araştırma sırasında RYVV'nin Yeni Zelanda'nın birçok bölgesinde olduğu doğrulanmıştır. Araştırıcılar RYVV'nin aşılama yoluyla taşınabildiğini, ancak yaprak biti veya mekanik yolla taşınmadığını bildirmişlerdir. Ayrıca RYVV ile enfekteli gül örneklerinde damar bantlaşması veya merkezi damar klorozunun yaygin bir şekilde görüldüğü belirtilmiştir (Lockhart ve ark., 2011).

RYVV ülkemizde ilk olarak Karanfil ve ark. (2018) tarafından rapor edilmiştir. Ülkemiz için yeni bir virüs hastalığı olan RYVV ile ilgili son derece sınırlı sayıda çalışma vardır (Karanfil ve ark., 2018; Karanfil, 2021). Bu bağlamda etmenin Çanakkale ilindeki yaygınlığı ve iki farklı gen bölgesine göre genetik çeşitliliği bu çalışma kapsamında araştırılmıştır.

\section{Materyal ve Yöntem}

Çalışmalar temel olarak 4 aşamada gerçekleştirilmiştir. Öncelikle Çanakkale ili ve ilçelerindeki park ve bahçe gibi alanlarda bulunan güller görsel olarak incelenmiş, virüs ve virüse benzer belirtiler gösterenlerden örnekler toplanarak laboratuvara getirilmiştir. İkinci aşamada alınan örneklerdeki RYVV'nin enfeksiyonunun belirlenmesi amacı ile örnekler PCR ile test edilmiştir. PCR testleri sonuçlarına göre RYVV ile enfekteli olduğu tespit edilen örnekler, sonrasında ileri analizler yapmak için bir kısmı silika jel içerisinde $4^{\circ} \mathrm{C}$ 'de, kalan kısım ise $-80^{\circ} \mathrm{C}^{\prime} \mathrm{de}$ saklanmıştır. Üçüncü aşama olan moleküler karakterizasyon çalışmalarında PCR testi sonucu pozitif çıkan örnekler içerisinden bir izolat seçilerek, ilgilenilen $M P$ (hareket proteini, movement protein) ve $C P$ (k1lıf proteini, coat protein) gen bölgeleri PCR ile amplifiye edilmiştir. Elde edilen PCR ürünleri kullanılarak seçilen izolata ait amplifiye edilmiş olan $M P$ ve $C P$ genlerinin nükleotid dizilimleri hizmet alımı ile belirlenmiştir. Son aşamada ise elde edilen RYVV $M P$ ve $C P$ genlerine ait nükleotid dizilimleri kullanılarak, amino asit dizilimleri çıkarılmıştır. Elde edilen bu diziler kullanılarak dünya RYVV izolatları ile Çanakkale RYVV izolatının filogenetik ilişkileri ortaya konmuştur.

\subsection{Arazi Çalışmaları}

Arazi çalışmaları 2018-2019 yılları ilkbahar ve yaz aylarında Çanakkale ili ve ilçelerinde gül bitkilerinin bulunduğu park, bahçe gibi rekreasyon alanlarında yürütülmüştür. Bu alanlarda yetiştirilen gül bitkileri görsel olarak incelenmiş RYVV'nin oluşturduğu simptomlara benzer simptom gösteren bitkilerden örnek alınmıştır. Örnekleme yapılan alanlar tamamen tesadüfi olarak seçilmiştir. Yapılan arazi çıkışları sonucunda 71 örnek toplanmıştır (Şekil 1). Toplanan örnekler laboratuvara soğuk zincirde muhafaza edilerek getirilmiş ve bir sonraki aşamaya kadar silika jel içinde buzdolabında bekletilmiştir. 


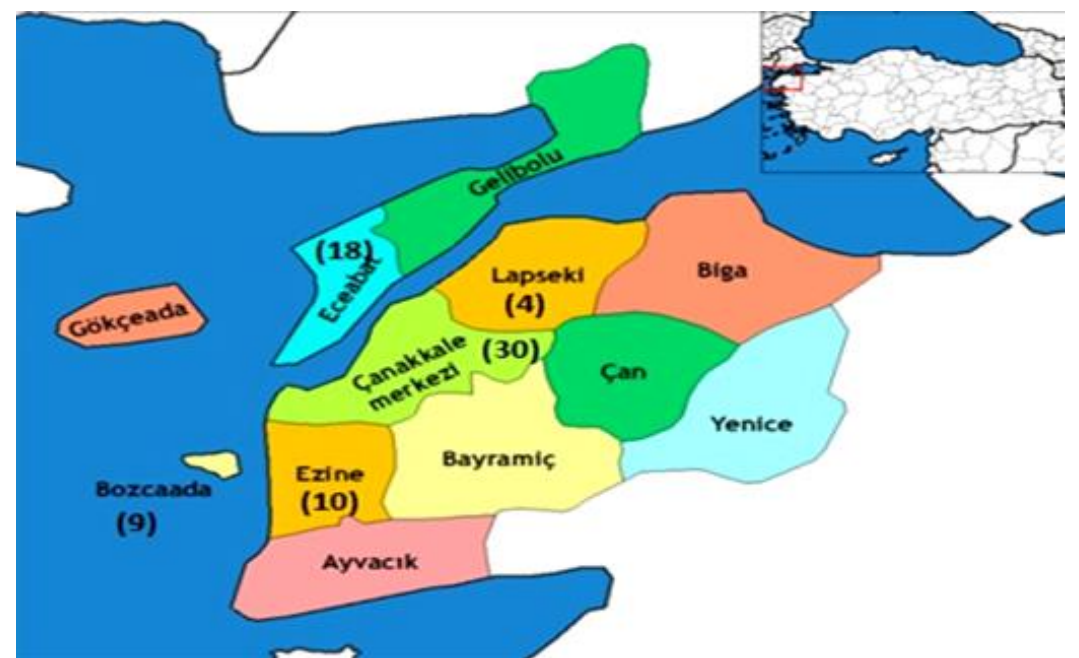

Şekil 1. Arazi çalışmalarının gerçekleştirildiği Çanakkale ilçeleri (Parantez içindeki rakamlar toplanan örnek sayılarını göstermektedir)

Figure 1. Çanakkale districts where field studies were carried out (Figures in parentheses show the number of samples collected)

\subsection{Polimeraz, Zincir Reaksiyonu Analizleri}

Toplanan örneklerdeki RYVV enfeksiyonunu tespit etmek amacı ile gerçekleştirilen polimeraz zincir reaksiyonu (polymerase chain reaction, PCR) çalışmalarına total DNA izolasyonu ile başlanmıştır. Total DNA izolasyonunu takiben gen spesifik primer çifti ile PCR testleri gerçekleştirilerek RYVV enfeksiyonu araştırılmıştır. Total DNA izolasyonu Li ve ark. (2008)'nın belirttiği şekilde gerçekleştirilmiştir. Örneklerdeki virüs varlığı ise Karanfil ve ark. (2018)'nın belirttiği primer çifti ve PCR koşulları uygulanarak araştırılmıştır (Çizelge 1).

Çizelge 1. Rose yellow vein virus enfeksiyonunun belirlenmesinde kullanılan primer çifti

Table 1. Primer pairs used in determination of Rose yellow vein virus infection

\begin{tabular}{|c|c|c|c|}
\hline Primer Dizisi (5'-3') & Yönü & Ürün & Referans \\
\hline $\begin{array}{c}\text { CGAGATTAACGAAATGGAC } \\
\text { CGTACTCTTTCTTGGCTT }\end{array}$ & $\begin{array}{l}\text { İleri } \\
\text { Geri }\end{array}$ & 766 bç & $\begin{array}{l}\text { Karanfil ve ark. } \\
\text { (2018) }\end{array}$ \\
\hline
\end{tabular}

RYVV ile enfekteli olarak bulunan bir izolat $C P$ ve $M P$ gen bölgelerine göre moleküler karakterizasyonu amac1 ile seçilmiştir. Seçilen izolatın hedef gen bölgeleri Çizelge 2'deki primer çiftleri kullanılarak PCR ile amplifiye edilmiştir.

\subsection{Sekanslama, Benzerlik ve Filogenetik Analizler}

PCR ile çoğaltılan RYVV $C P$ ve $M P$ genlerine ait PCR ürünlerinin saflaştırma işlemi EZ Column PCR pürifikasyon kiti (BioBasic, Kanada) kullanılarak üretici firmanın önerileri yönünde gerçekleştirilmiştir. PCR ürünleri sekansa gönderilinceye kadar $-20^{\circ} \mathrm{C}^{\prime}$ de muhafaza edilmiştir. Gerçekleştirilen sekanslama işlemi ile birlikte RYVV izolatının DNA baz dizilimleri hizmet alımı ile çift yönlü olarak belirlenmiştir (BM Labosis, Ankara). Elde edilmiş olan çift yönlü DNA dizilerinden konsensüs diziler elde edilmiştir. Ayrıca bu dizilerin kodladığı aminoasit içerikleri de belirlenmiştir.

RYVV $C P$ ve $M P$ genlerinin DNA dizilimleri, dünyanın farklı bölgelerinden gen bankasına kaydedilmiş olan, RYVV izolatlarının $C P$ ve $M P$ genlerinin DNA dizileriyle karşılaştırılmıştır. Bu amaçla DNA dizileri CLC Main Work Bench V.7.9.1 programında Clustal W kullanılarak nükleotid ve aminoasit düzeyinde karşıllaştırılmıştır. Ayrıca dünya izolatları ile benzerlikleri ortaya koyulmuştur. 
Çalışmada 8'i dünyanın farklı yerlerine ait ve 1'i Çanakkale'den olmak üzere toplamda 9 izolat arasında incelemeler yapılmıştır. Çanakkale izolatı için CNK öneki kullanılarak adlandırılmıştır. Çalışmada kullanılan dünya izolatlarına ait gen bankası erişim numaraları ve elde edildiği ülke (orijin) bilgileri Çizelge 3'de verilmiştir.

Çizelge 2. Rose yellow vein virus'un kılıf ve hareket proteinlerinin amplifikasyonu için kullanılan primer çiftleri* Table 2. Primer pairs used for amplification of coat and movement proteins of Rose yellow vein virus

\begin{tabular}{cccc}
\hline Virüs & Lokus & Dizi & Ürün (bç) \\
\hline \multirow{3}{*}{ RYVV } & RYVV_F2 $(1088,1105)$ & GGATGACAGAAGGAAAGG & \multirow{2}{*}{1508} \\
& RYVV_R2 $(2578,2595)$ & GGCAGTATTAGGGAGAGA & \multirow{2}{*}{1481} \\
& RYVV_F3 $(2325,2341)$ & TAACGAAATGGACACCT & \\
\hline
\end{tabular}

*Kullanılan bu primer çiftleri FBA-2019-2891 numaralı proje kapsamında tasarlanmıştır.

Çizelge 3. Dünyanın diğer bölgelerindeki Rose yellow vein virus izolatlarının numaraları ve orijinleri

Table 3. Numbers and origins of Rose yellow vein virus isolates from other countries in the world

\begin{tabular}{cc}
\hline Erişim Numaraları & Elde Edildiği Ülke \\
\hline JX887423 & Yeni Zelanda \\
JX430789 & Yeni Zelanda \\
JX887424 & Yeni Zelanda \\
JX430788 & Yeni Zelanda \\
JX028536 & ABD \\
JX887426 & Yeni Zelanda \\
JX887425 & Yeni Zelanda \\
MH395928 & Türkiye
\end{tabular}

Filogenetik ilişkileri belirlemek amacıyla Neighbor-joining yöntemi kullanılarak filogenetik soy ağaçları her iki gen bölgesi için oluşturulmuştur. Bununla birlikte soy ağacının doğruluğunun istatistiksel olarak belirlenmesi maksadıyla 1000 tekerrürlü bootstrap analizi yapılmış ve Çanakkale RYVV izolatının diğer izolatlarla filogenetik ilişkileri ortaya koyulmuştur.

\section{Bulgular ve Tartışma}

Arazi çalışmaları Çanakkale'de 2018-2019 bahar sezonlarında gerçekleştirilmiştir. Arazi çıkışı yapılan alanlar rastgele seçilmiş ve bitkiler görsel olarak incelenerek bunlardan RYVV benzeri simptom gösteren güllerden örnekler alınmıştır. Arazi çalışmaları sonucunda toplamda 71 örnek toplanmıştır. Yapılan PCR testleri sonucunda 71 örneğin 19'u RYVV ile enfekteli olarak bulunmuştur. PCR çalışmalarında enfekteli bulunan örnekler virüse özgü 766 bç büyüklüğünde bant oluşturmuştur. Negatif kontrol ve su örneğinde ise herhangi bir bant oluşmamıştır.

Virüs tanılama çalışmalarında herhangi bir zorlukla karşılaşılmamış, enfekteli örneklerde istenen büyüklük ve parlaklıkta bantlar elde edilmiştir (Şekil 2). PCR analizleri virüslerin tanısında yaygın olarak ve başarılı bir şekilde kullanılmaktadır. Duyarlılığı çok yüksek olup, kısa sürede sonuç alınmaktadır. Karanfil ve ark. (2018) yaptıkları bir ön çalışmada Çanakkale ve Ankara illerinden topladıkları gül örneklerini RYVV için PCR ile testlemişler ve testlemeler sonucunda etmenin varlığını belirlemişlerdir. Çalışma kapsamında Merkez ilçeden toplanan 30 örneğin 8'i, Eceabat'tan toplanan 18 örneğin 5'i, Lapseki'den toplanan 4 örneğin 3'ü ve Ezine'den toplanan 10 örneğin 3'ü RYVV ile enfekteli olarak bulunmuştur. Bozcaada'dan toplanan 9 örneğin hiçbirinde RYVV bulunamamıştır. Toplanan örneklerde ilçe bazında en yüksek enfeksiyon oranı \%75.0 ile Lapseki ilçesinden elde edilirken bunu 
\%30.0 ile Ezine, \%27.7 ile Eceabat ve \%26.6 ile Merkez ilçe izlemiştir. Toplamda enfeksiyon oranı \%26.8 olmuştur (Çizelge 4).

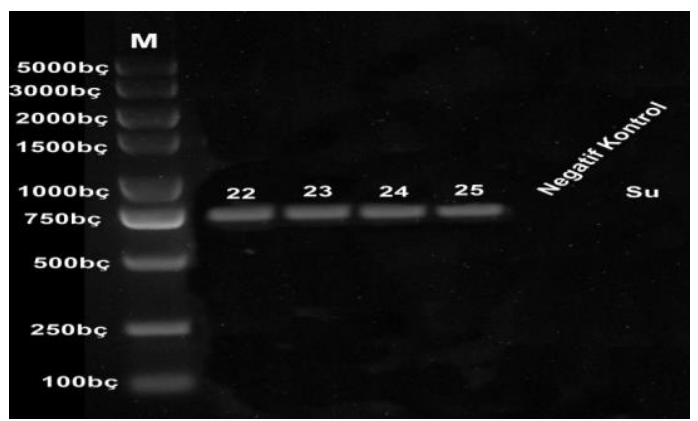

Şekil 2. Araziden toplanılan bazı gül örneklerin polimeraz zincir reaksiyonu ile testlenmesi sonucu elde edilen agaroz jel görüntüsü $(22,23,24$ ve 25 : gül örnek numaraları).

Figure 2. Agarose gel image obtained by polymerase chain reaction testing of some rose samples collected from the field (22, 23, 24 and 25: rose sample numbers).

Arazi çalışmaları kapsamında güllerde yapraklarda çizgili lekeler, rozetleşme, solgunluk, halkalı lekeler, yaprak kıvırcıklığı, cücelik, çiçeklerde ise renk açılmaları ve şekil bozukluklarına benzer belirtiler gözlenmiştir. Bu belirtileri gösteren ve PCR sonucu enfekteli bulunan gül bitkisi örnekleri Şekil 3'de verilmiştir.

Çizelge 4. Çanakkale ili ve ilçelerinden alınan örnek sayıları, enfekteli örnek sayıları ve enfeksiyon oranları

Table 4. Number of samples taken from Çanakkale province and its districts, number of infected samples and infection rates

\begin{tabular}{ccc} 
Örnek alınan ilçeler & $\begin{array}{c}\text { Enfekteli örnek sayıs1/ } \\
\text { Alınan örnek sayıs1 }\end{array}$ & $\begin{array}{c}\text { Toplanan Örneklerdeki } \\
\text { Enfeksiyon oranı (\%) }\end{array}$ \\
\hline Merkez & $8 / 30$ & 26.6 \\
Eceabat & $5 / 18$ & 27.7 \\
Lapseki & $3 / 4$ & 75.0 \\
Ezine & $3 / 10$ & 30.0 \\
Bozcaada & $0 / 9$ & 0 \\
Toplam & $19 / 71$ & 26.8 \\
\hline
\end{tabular}

Toplanan örnekler içerisinden RYVV benzeri simptom gösteren ancak enfekteli bulunmayan örneklerin büyük olasılıkla başka virüs ya da virüslerle enfekteli olduğu düşünülmektedir. Nitekim Horst ve Cloyd (2007), çalışmalarında güllerde görülen 11 farklı virüs hastalığını tanımlamışlardır. Bunlar arasında en yaygın olanlarını ApMV, PNRSV ve ArMV olarak bildirmişlerdir. Bununla birlikte güllerde cüceliğe, şekil bozukluklarına ve köşeli sar1 yaprak lekelerine neden olan Strawberry latent ringspot virus (SLRSV)'ü ise bir başka virüs hastalığı olarak belirtmişlerdir. Nitekim içinde Çanakkale ilinin de olduğu gül virüs hastalıklarıyla ilgili olarak gerçekleştirilen bir çalışmada da RYVV'nin güllerin önemli bir hastalığı olduğu belirtilirken, Türkiye güllerinde enfeksiyonu en fazla rastlanılan etmenin PNRSV olduğu belirtilmiştir (Karanfil, 2021).

Gen bankası veri tabanlarında dünyanın farklı üretim bölgelerinden elde edilen sınırlı sayıda RYVV izolatının $C P$ ve $M P$ genlerini içeren bölgelerinin dizilimi bulunmaktadır. Gen bankasında bulunan bu genlerin nükleotid ve amino asit dizilimleri alınarak Çanakkale ili ve ilçelerinden elde edilen RYVV izolatı $C P$ ve $M P$ genlerinin nükleotid ve amino asit dizilimleri ile karşılaştırarak RYVV-CNK izolatının diğer uluslararası izolatlar ile gösterdiği benzerlik oranları ve filogenetik ilişkileri belirlenmiştir.

Nükleotid temelli dizi analizi incelemelerinde $C P$ genine göre Çanakkale RYVV izolatı ile dünya izolatlarının benzerlik oranları karşılaştırıldığında en yüksek benzerliğin \%98 oranla RYVV-CNK-CP ile MH395928 izolatları arasında olduğu görülmüştür. Bu iki izolatta ülkemize aittir ve yüksek oranda benzerlik gösterdikleri belirlenmiștir. İkinci en yüksek benzerlik oranının ise RYVV-CNK-CP ile JX028536 numaralı Amerika izolatı arasında olduğu saptanmıştır (Şekil 4a). Amino asit temelli benzerlik dizi analizlerinde RYVV-CNK izolatının $C P$ geni amino asit benzerlikleri incelendiğinde en yüksek benzerliği \%99 oranla JX028536 numaralı Amerikan izolatı ile göstermiştir (Şekil 4b). 

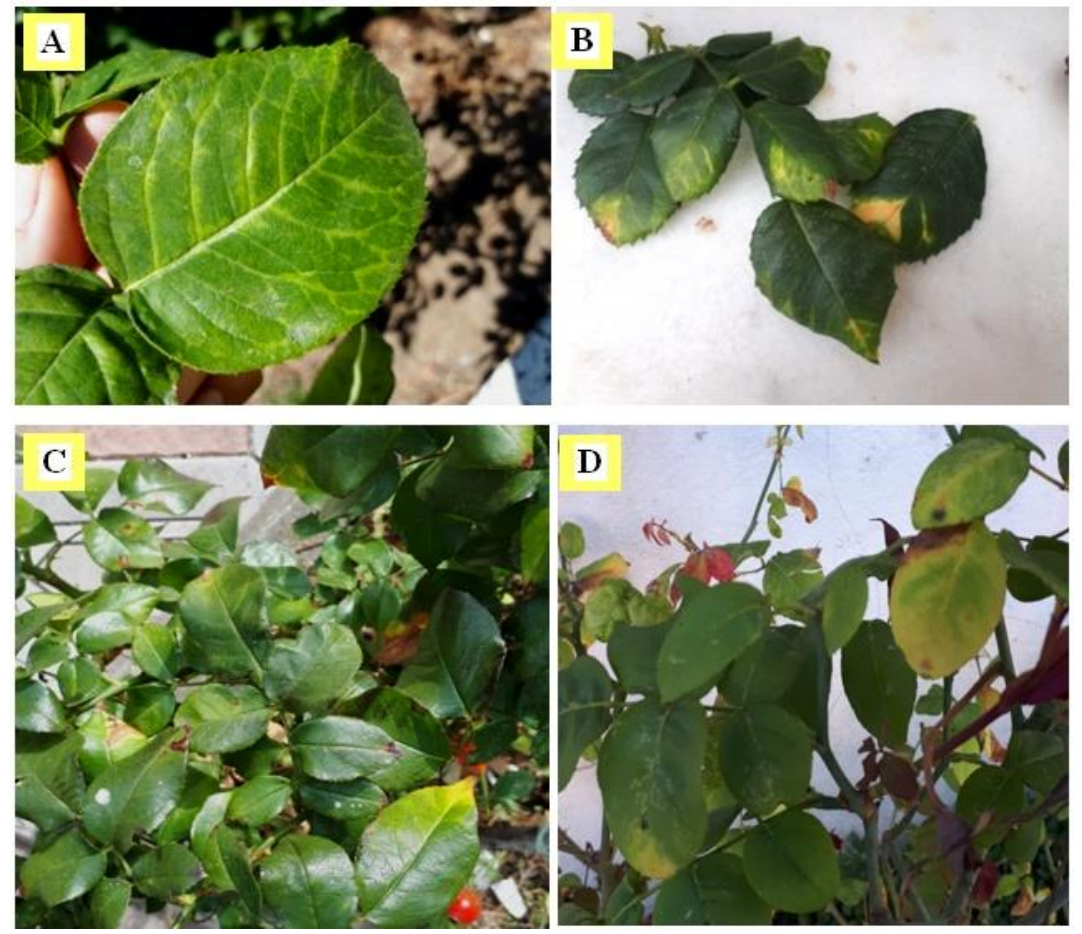

Şekil 3. Arazide Rose yellow vein virus benzeri simptom gösteren ve PCR testlemelerinde enfekteli bulunan gül bitkileri (A: Damarlarda renk açılması; B: Yaprak uçlarındaki damarlarda sararma; C: Yapraklarda renk değişimi; D: Damarlarda ve yapraklarda sararma).

Figure 3. Rose plants showing Rose yellow vein virus-like symptoms in the field and found as infected in PCR tests (A: Discoloration of veins; B: Yellowing of veins at leaf tips; C: Discoloration of leaves; D: Yellowing of veins and leaves).

$M P$ genine göre benzerlik oranları incelendiğinde RYVV-CNK izolatının diğer dünya izolatları ile \%97-98 arasında benzerlik gösterdiği görülmüştür. En düşük benzerlik oranının Çanakkale izolatı ile ABD izolatı arasında \%97 oranında olduğu belirlenmiştir. Çanakkale izolatı ile en yüksek benzerlik oranının ise JX887424 erişim numaralı Yeni Zelanda izolatı ile \%98 oranında göstermiş̦tir. Genel olarak en fazla benzerliğin \%100 oranla JX887424 erişim numaralı ve JX430788 erişim numaralı Yeni Zelanda izolatlarının birbirleri arasında olduğu görülmüştür (Şekil 4c). RYVV hareket proteini genlerine göre yapılan aminoasit temelli benzerlik analizleri sonucunda RYVV dünya izolatları ile Çanakkale izolatı arasında \%99 oranla benzerlik bulunduğu görülmüştür (Şekil 4d). Dünyada RYVV ile gerçekleştirilen sınırlı sayıdaki çalışmada da bu çalışma sonuçlarını destekler bulgular elde edilmiştir. Perez Egusquiza ve ark. (2012) tarafından Yeni Zelanda'da gerçekleştirilen başka bir çalışmada ise Yeni Zelenda RYVV izolatı $C P$ geninin \%96 oranlarında benzerlikler gösterdiğini tespit etmişlerdir. Karanfil ve ark. (2018) tarafından ülkemizde gerçekleştirilen çalışma sonuçlarına göre elde ettikleri Türk RYVV izolatı ile dünya RYVV izolatları arasında \% 97-98 oranında benzerlik olduğunu belirtmişlerdir.

Filogenetik soyağacı kılıf protein genleri nükleotit dizilimlerine göre incelendiğinde 2 ana gruba ayrıldığ 1 görülmüştür. Birinci ana grup RYVV-CNK-CP, JX028536, MH395928 olmak üzere 3, ikinci ana grup JX887425 ve JX887426 olmak üzere 2 izolat içermektedir. Birinci ana grupta Çanakkale, Türkiye ve ABD izolatları yer alırken ikinci grup Yeni Zelanda izolatlarından oluşmuştur. Çanakkale RYVV izolatı ve dünya izolatlarının kılıf protein genine göre nükleotid dizilimleri kullanılarak oluşturulan filogenetik soyağacı Şekil 5 'te verilmiştir.

Çanakkale RYVV izolatı ile dünya izolatlarının hareket proteini genine göre nükleotid dizilimleri kullanılarak oluşturulan filogenetik soyağacı Şekil 6'da verilmiştir Şekilde de görüldüğü gibi filogenetik soyağacı 2 ana gruptan oluşmuştur. Birinci ana grupta JX887423, JX430789, JX887424, JX430788 ve RYVV-CNK-MP olmak üzere 5, ikinci ana grupta JX028536 olmak üzere bir izolat yer almıştır. Yeni Zelanda ve Çanakkale izolatları aynı ana grupta yer alırken ABD izolatı diğer ana gruba dahil olmuştur. Çanakkale RYVV izolatının bazı dünya izolatları ile oluşturduğu soy ağacının dalları 31-85 arasında değişen bootstrap değerleri ile doğruluğu desteklenmiştir. Bu değerler, sonuçların tesadüfi olmadığını ve soyağacındaki dallardan birçoğunun istatistiksel açıdan desteklendiğini göstermiştir. 


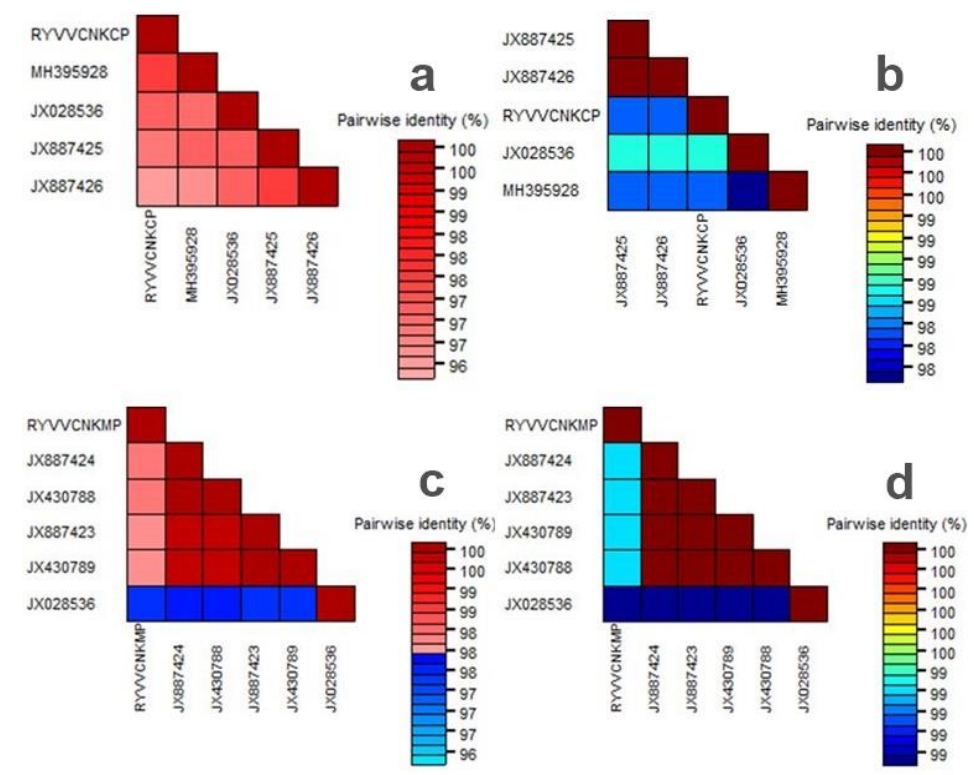

Şekil 4. Çanakkale Rose yellow vein virus (RYVV) izolatı ile dünyadaki RYVV izolatlarının kılıf protein (CP ) ve hareket protein (MP) gen bölgelerine göre benzerlik oranları (a-b: CP genine göre sırası ile nükleotit ve amino asit düzeyinde benzerlik oranı; c-d: MP genine göre sırası ile nükleotid ve amino asit düzeyinde benzerlik oranı).

Figure 4. Similarity rates of Çanakkale Rose yellow vein virus (RYVV) isolate and RYVV isolates in the world according to coat protein (CP) and movement protein (MP) gene regions (a-b: nucleotide and amino acid level similarity rates based on the $\mathrm{CP}$ gene, respectively; c-d: nucleotide and amino acid level similarity rates based on the MP gene, respectively).

Karanfil (2021) tarafından güllerdeki virüs hastalıklarının belirlenmesine yönelik gerçekleştirilen çalışmada da RYVV izolatlarının $C P$ gen bölgesinin kısmi dizilerine göre 3 farklı filogenetik grup oluşumu olduğunu bildirmiştir. Bu bağlamda elde edilen sonuçlar birbirini destekler niteliktedir.

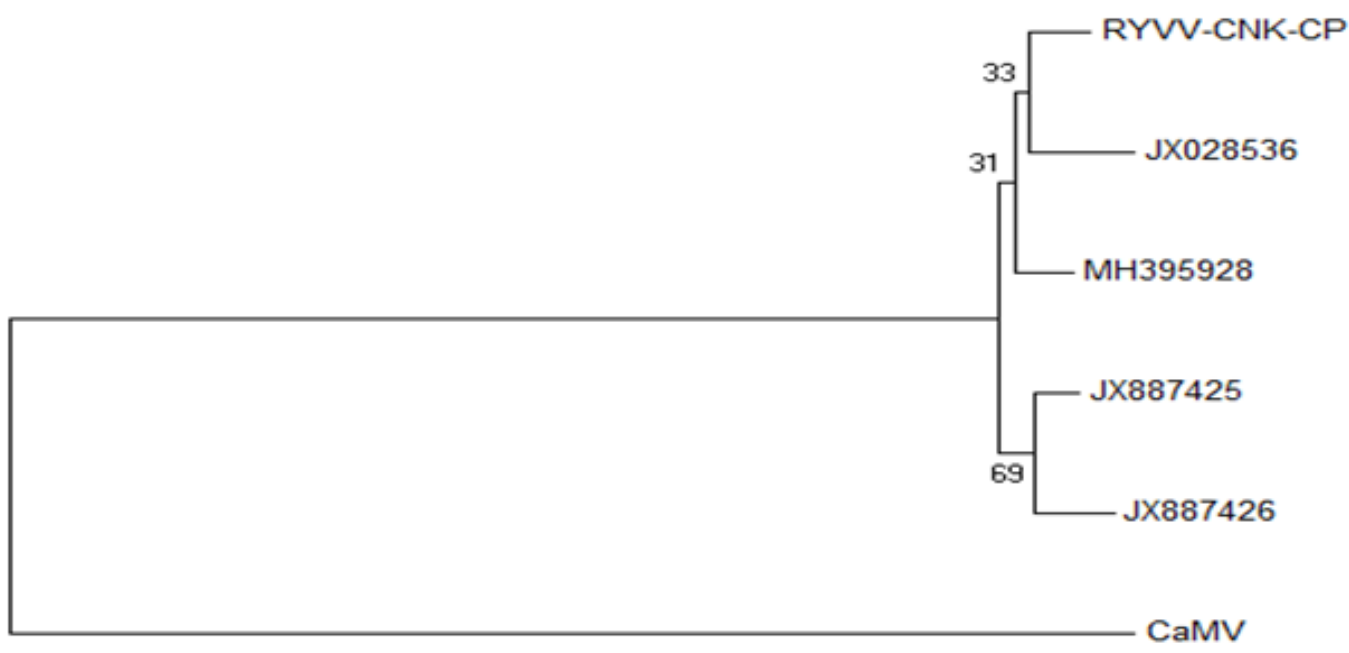

Şekil 5. Çanakkale Rose yellow vein virus izolatının kılıf protein geninin nükleotid dizilimleri kullanılarak neighborjoining yöntemi ile oluşturulan filogenetik soyağacı [Cauliflower mosaic virus (CaMV) dış grup olarak filogenetik ağaçta kullanılmıştır. Genbankası erişim no: M90543]

Figure 5. The phylogenetic tree of Rose yellow vein virus isolates based on the nucleotide sequences of the coat protein protein-coding genome [The phylogenetic tree was constructed by the neighbor-joining and Cauliflower mosaic virus (M90543) was used an outgroup] 


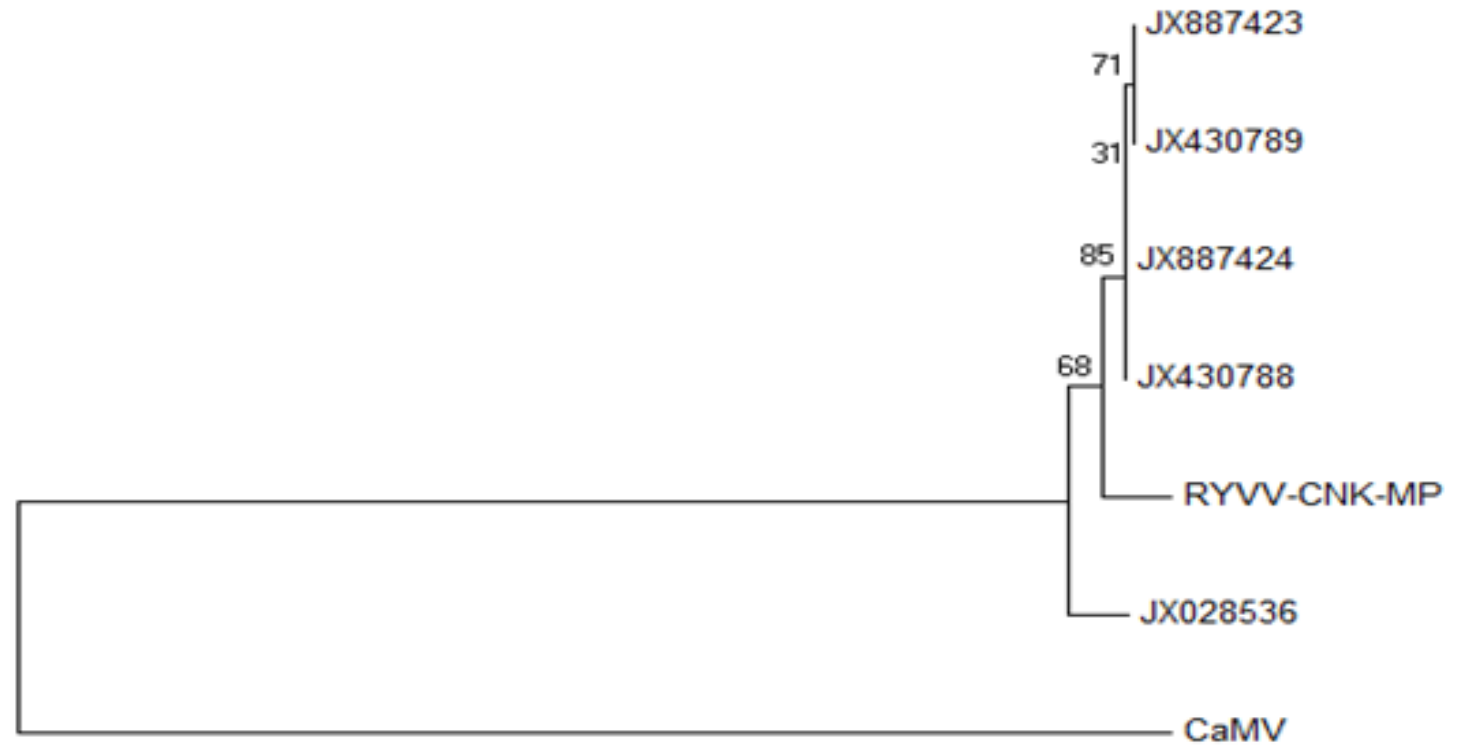

Şekil 6. Çanakkale Rose yellow vein virus izolatının hareket protein geninin nükleotid dizilimleri kullanılarak neighbor-joining yöntemi ile oluşturulan filogenetik soyağacı [Cauliflower mosaic virus (CaMV) dış grup olarak filogenetik ağaçta kullanılmıştır. Genbankası erişim no: M90543]

Figure 6. The phylogenetic tree of Rose yellow vein virus isolates based on the nucleotide sequences of the movement protein-coding genome [The phylogenetic tree was constructed by the neighbor-joining and Cauliflower mosaic virus (M90543) was used an outgroup]

\section{Sonuç}

Bundan sonra gerçekleştirilecek çalışmalarda RYVV izolatlarının tüm genom dizilimlerinin belirlenmesine ve ülkemizde RYVV izolatlarının vektör ya da vektörlerinin olup olmadığının tespitine yönelik olarak çalışmaların gerçekleştirilmesi gerektiği düşünülmektedir.

\section{Kaynaklar}

Anonim, 2016. Türkiye İstatistik Kurumu, TÜİK. http://www.tuik.gov.tr/PreTablo.do?alt_id 1001 Erişim tarihi: 23.08.2017

Horst, R.K., Cloyd, R., 2007. Compendium of Rose Disease and Pests. APS Press, İkinci Bask1, 96s, Minnesota, ABD.

Karanfil, A., 2021. Prevalence and molecular characterization of Turkish isolates of the rose viruses. Crop Protection, 143: 105565.

Karanfil, A., Randa-Zelyüt, F., Ertunç, F., Korkmaz, S., 2018. First report of Rose yellow vein virus in Turkey. New Disease Reports, 38: 11.

Korkut, A.B., 1998. Gül Yetişitiriciliği. Hasad Yayıncılık s: 28-43.

Li, R., Mock, R., Huang, Q., Abad, J., Hartung, J., Kinard, G.A., 2008. A reliable and inexpensive method of nucleic acid extraction for the PCR-based detection of diverse plant pathogens. J Virol Methods 154: 48-55.

Lockhart, B., Zlesak, D., Fetzer, J., 2011. Identification and partial characterization of six new viruses of cultivated roses in the USA. Acta Hort, 901: 139-147.

Milleza, E.J.M., Ward, L.I., Delmiglio, C., Tang, J.Z., Veerakone, S., Perez-Egusquiza, Z., 2013. Received: A survey of viruses infecting Rosa spp. in New Zealand Australasian. Plant Pathology, 42(3): 313-320.

Perez-Egusquiza, Z., Liefting, L.W., Ward, L.I., 2012. First Report of Rose yellow vein virus in Rosa sp. in New Zealand. APS Journals. Plant Disease, 97(8): 1122.

Titiz, S., Çakıroğlu, N., Yıldırım, T.B., Çakmak, S., 2000. Süs Bitkileri Üretim ve Ticaretindeki Gelişmeler. Türkiye Mühendisler ve Mimarlar Odası Ziraat Mühendisleri Odası, Kongresi, Ankara.

Yazgan, M.E, Korkut, A.B., Barış, E., Erkal, S., Yılmaz, R., Erken, K., Gürsan, K., Özyavuz, M., 2005. Süs Bitkileri Üretiminde Gelişmeler. Ziraat Mühendisleri Odası VI. Türkiye Ziraat Mühendisliği Teknik Kongresi, Ankara.

Yılmaz, İ., 2009. Avrupa Birliği’ne Uyum Sürecinde Türk Kesme Çiçek Sektörünün Swot (Gtzf)Analizi. Akdeniz Üniversitesi Ziraat Fakültesi Dergisi, 22(1):103-112. 